\title{
INFLUENCE OF PLANT SPACING ON THE BARK PROPERTIES OF A Eucalyptus CLONE ${ }^{1}$
}

Maria Fernanda Vieira Rocha ${ }^{2 *}$, Bárbara Luísa Corradi Pereira ${ }^{3}$, Aylson Costa Oliveira ${ }^{3}$, Matheus Felipe Freire $\mathrm{Pego}^{4}$, Taís Regina Lima Abreu Veiga ${ }^{4}$ and Angélica de Cássia Oliveira Carneiro ${ }^{5}$

\footnotetext{
${ }^{1}$ Received on 07.03.2016 accepted for publication on 28.06.2018.

${ }^{2}$ Universidade Federal de Lavras, Doutora em Ciência e Tecnologia da Madeira, Lavras, MG - Brasil. E-mail:<mfvrocha@yahoo.com.br>. ${ }^{3}$ Universidade Federal de Mato Grosso, Faculdade de Engenharia Florestal, Cuiabá, MT - Brasil. E-mail: <babicorradi@gmail.com> and < aylsoncosta@gmail.com>.

${ }^{4}$ Universidade Federal de Lavras, Programa de Pós-Graduação em Ciência e Tecnologia da Madeira, Lavras, MG - Brasil. E-mail:<matheuscura@hotmail.com>and<tr.abreu@hotmail.com>.

${ }^{5}$ Universidade Federal de Viçosa, Departamento de Engenharia Florestal, Viçosa, MG - Brasil. E-mail: <cassiacarneiro1@gmail.com>.

*Corresponding author.
}

\begin{abstract}
For several wood uses, such as pulp, paper and charcoal, the presence of the bark is undesirable, compromising production. Thus, this study aimed to evaluate the influence of different plant spacings on the properties of the bark of a clone of Eucalyptus grandis $x$ E. camaldulensis at seven years of age at five different plant spacings. The wood discs were removed from the trees at $0,25,50,75$ and $100 \%$ of the commercial height; then we performed thickness, basic density, gross calorific value and mineral content analysis of bark. There were no significant differences among treatments for the bark gross calorific value and thickness. For the bark basic density, the highest values were found in trees planted in wider plant spacings and considering the mineral content, there was a significant difference only for $\mathrm{P}, \mathrm{Mn}$ and $\mathrm{Zn}$.
\end{abstract}

Keywords: Quality; Minerals; Forest planting.

\section{INFLUENCIA DO ESPAÇAMENTO DE PLANTIO NAS PROPRIEDADES DA CASCA DE UM CLONE DE Eucalyptus}

\begin{abstract}
RESUMO - Para diversos usos da madeira, como na produção de celulose e papel e do carvão vegetal, a presença da casca é indesejável, podendo comprometer a produção. Desta forma, este trabalho teve como objetivo avaliar a influência de diferentes espaçamentos de plantio nas propriedades da casca de um clone de Eucalyptus grandis $\mathrm{x}$ E. camaldulensis aos sete anos de idade em cinco diferentes espaçamentos de plantio. Os discos de madeira foram retirados das árvores nas posições $0,25,50,75$ e 100\% da altura comercial. Foram feitas análises da espessura, densidade, poder calorífico superior e minerais da casca. Não houve diferenças significativas entre os tratamentos para o poder calorifico e para a espessura da casca. Para a densidade básica da casca, os maiores valores foram encontrados nas árvores plantadas nos maiores espaçamentos e considerando os teores de minerais, houve diferença significativa apenas para P, Mn e Zn.
\end{abstract}

Palavras-Chave: Qualidade; Minerais; Plantio florestal. 


\section{INTRODUCTION}

Recent years have seen a significant increase in biomass production for energy purposes. This is mainly due to fluctuations in supply and price of fossil fuels, the increase in energy consumption and the environmental benefits it offers, such as the reduction of greenhouse gas emissions due to the uptake of $\mathrm{CO}_{2}$ by forests and reducing the amount of sulfur produced, since the biomass has practically none of this component (Rocha, 2011).

According to Hall (1991), biomass provides about $14 \%$ of worldwide energy consumption and, on average, $35 \%$ of consumption in developing countries. Wood has always contributed to the development of humankind and was the first power source initially employed for heating and food preparation. Over the years, solid, liquid and gaseous fuel came to be used, forming processes for generating thermal, mechanical and electrical.

Within this context, the use of forest plantations aimed at the production of biomass for power generation contributes to a more sustainable environmental perspective, because it has salvage timber and consequently the return of residues (bark, branches, and leaves) to the soil.

Andrade (1989) found that the inclusion of the bark in the carbonization provides significant increases in gravimetric and fixed carbon yields, despite the substantial increase in ash content in the charcoal. When the charcoal is intended to produce some types of iron alloys or calcium carbide, the presence of some mineral components is undesirable. Thus, the phosphorus present in the charcoal is incorporated into metal alloys making them brittle, less flexible, providing favorable conditions for the propagation of cracks and fissures. Phosphorus results in brittle carbide stones, reducing its particle size and making it unsuitable for the production of many materials. Thus, the bark is been referenced as a portion of the tree that contributes minerals to the charcoal and despite representing an average of only 10 to $15 \%$ of the total volume of the tree, is treated as an undesirable portion (Vital et al., 1989).

Stappe et al. (1988) says that the eucalyptus bark, which represents $10-20 \%$ of log volume, is another residue that began to accumulate in deposits of industries that have installed large peelers and its use as raw material in boilers has resulted in technical issues such as the appropriate moisture content and high ash content.
The ash from burning wood and bark biomass is a waste product rich in nutrients for the plants.

Therefore, this study aimed to evaluate the effect of different plant spacings on the thickness and properties of the bark of Eucalyptus grandis $\mathrm{x}$ Eucalyptus camaldulensis.

\section{MATERIALAND METHODS}

We obtained the Eucalyptus bark from hybrid Eucalyptus grandis x Eucalyptus camaldulensis clones, 7 years old, from the forestry company located at the city Itamarandiba - MG.

Itamarandiba is a city located at the Jequitinhonha Valley region, Minas Gerais state, with geographic coordinates $17,86^{\circ} \mathrm{S}$ latitude and $42,86^{\circ} \mathrm{W}$ longitude (PNUD, 2000). The average temperature reaches $21,2^{\circ} \mathrm{C}$ and the climate is tropical of altitude, with two distinct seasons. The median rainfall is $1,130 \mathrm{~mm}$ annual and the maximum altitude is $1,658 \mathrm{~m}$ minimum of $645 \mathrm{~m}$. The cerrado biome is the main type of vegetation. (Brasil, 2005). The annual average relative humidity is $60-70 \%$ and the predominant soils in the region are ferric luvisols, acric ferrous and arenosols. (Müller, 2005).

The experiment was installed in December 2002 in a completely randomized design and the trees were harvested in January 2010. We made three replicates per treatment, divided into three blocks. Each block consisted of six plant lines ( $3 \mathrm{~m}$ distance between the lines), and in each line 28 trees were planted (the distance between the trees varied according to the treatment: $0.5,1.0,1.5,2.0$, and $3.0 \mathrm{~m}$ ) totaling 168 trees. In each block, the first two and the last two planting lines and the first two and the last two trees of each line were considered as edges. This resulted in 120 edge trees and 48 trees located inside the block, considered as belonging to the sample unit or section. Table 1, presents the characterization of the experiment:

Three dominant trees (repetitions) of each treatment were collected. From each tree, wood discs were removed at $0,25,50,75$ and $100 \%$ of commercial height. For each disc we obtained opposing wedges and for each of the wedges we obtained the bark for determination of the bark basic density. The rest of the bark on the wood disk was destined for other analyzes.

All analyzes were conducted at the Panels and Wood Energy Laboratory, Department of Forest Engineering, Federal University of Viçosa (UFV).

Revista Árvore. 2018;42(5):e420501

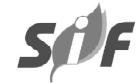


Table 1-Characteristics of the experimental population. Tabela 1-Características da população experimental.

Treatment Spacing Area Tree Tree Plot area
per plant Block Edge plot Tree

\begin{tabular}{ccccccr} 
& $(\mathrm{m})$ & $\left(\mathrm{m}^{2}\right)$ & & & & $\left(\mathrm{m}^{2}\right)$ \\
\hline 1 & $3.0 \times 0.5$ & 1.5 & 168 & 120 & 48 & 72 \\
2 & $3.0 \times 1.0$ & 3 & 168 & 120 & 48 & 144 \\
3 & $3.0 \times 1.5$ & 4.5 & 168 & 120 & 48 & 216 \\
4 & $3.0 \times 2.0$ & 6 & 168 & 120 & 48 & 288 \\
5 & $3.0 \times 3.0$ & 9 & 168 & 120 & 48 & 432 \\
\multicolumn{2}{r}{ Plant area $=$ area per plant $\left(\mathrm{m}^{2}\right) ;$ Tree per block $=$ Number of trees }
\end{tabular}
per block; Tree per edge $=$ Number of border trees; Tree per plot $=$ Number of trees per plot; Plot Area $=$ Area of plot $\left(\mathrm{m}^{2}\right)$.

The bark basic density was determined according to the norm of the Brazilian Association of Technical Norms - ABNT NBR 11941 (ABNT, 2003), using two opposing wedges of each longitudinal position of the trunk, and the determination of the basic density of the bark was taken as the arithmetic mean of the densities of the respective barks of the wedges.

The gross calorific value of the bark was determined by an adiabatic bomb calorimeter Ika model C 200, according to ABNT NBR 8633 (ABNT, 1983). By using a pachymeter in all discs obtained from each tree, measurements were made of the bark thickness, and the arithmetic mean calculated.

For the determination of the major elements, the samples were submitted to nitroperchloric digestion $(4: 1 \mathrm{v} / \mathrm{v})$, detection of $\mathrm{P}$ and $\mathrm{B}$ was via colorimetrics; $\mathrm{K}$ through photometrics. $\mathrm{Ca}, \mathrm{Mg}, \mathrm{Mn}, \mathrm{Cu}, \mathrm{Fe}$ and $\mathrm{Zn}$ by atomic absorption, $\mathrm{S}$ by turbidimetrics and $\mathrm{N}$ using the Kjeldahl method (Embrapa, 1997).

For statistical analysis, we used a completely randomized design with five treatments or plant spacings and three replicates (trees) per treatment.

We submitted the data to the Lilliefors test to test the normality, and Cochran, to test the homogeneity of variances.

The results were then submitted to analysis of variance (ANOVA), to verify the differences among the plant spacings. Having established significant differences among them, we applied the Tukey test at $95 \%$ significance level.

\section{RESULTS}

According to the results shown on table 2, there is a significant difference between treatments for basic density; however, there were no significant differences in the thickness and gross calorific value of bark. The basic density values for spacing $1(3 \times 0.5 \mathrm{~m})$ obtained was the lowest among the treatments and did not differ significantly from treatments 2 ( $3 \times 1 \mathrm{~m}), 3(3 \times 1.5 \mathrm{~m})$ and $4(3 \times 20 \mathrm{~m})$. The higher value of bark basic density was on spacing $5(3 \times 3 \mathrm{~m})$, which this value is approximately $5 \%$ higher than the basic density value obtained in the spacing $1(3 \times 0.5 \mathrm{~m})$.

Table 3 and 4 showed the average value of the minerals present in bark depending on spacing. Most nutrient values did not differ significantly between treatments, only the nutrients $\mathrm{P}, \mathrm{Zn}$ and $\mathrm{Mn}$.

Figure 1 shows the mean values of phosphorus, zinc and manganese, respectively, present in the bark, depending on the spacing between trees. At the 3.0 $\mathrm{x} 1.0 \mathrm{~m}$ spacing we obtained the highest levels of phosphorus in the bark, however, these values did not differ significantly from those found at $3.0 \times 0.5$ and $3.0 \times 1.5 \mathrm{~m}$. As for the zinc values, one can see a difference of $22.89 \%$ between the $3.0 \times 3.0 \mathrm{~m}$ spacing and the $3.0 \times 0.5 \mathrm{~m}$ spacing, where the highest content of this nutrient was found, which however, did not differ significantly from the $3.0 \times 1.0 ; 3.0 \times 1.5$ and 3.0 $\mathrm{x} 2.0 \mathrm{~m}$ spacings. For the manganese values, a different behavior was observed for phosphorus and zinc. The wider spacing $(3.0 \times 2.0 \mathrm{~m} ; 3.0 \times 3.0 \mathrm{~m})$ presented the highest nutrient levels, which however, did not differ significantly from those found at the $3.0 \times 1.0 \mathrm{~m} 3$ and $0 \times 1.5 \mathrm{~m}$ spacings. In the $3.0 \times 0.5 \mathrm{~m}$ spacing one may notice a difference of $61.81 \%$ in relation to the wider spacing, at which the highest concentration of manganese was found.

Table 2 - Mean values of basic density, thickness and gross calorific value (GCV) of Eucalyptus bark, depending on the plant spacing.

Tabela 2 - Valores médios da densidade básica, espessura e poder calorifero da casca de Eucalyptus em função do espaçamento de plantio.

\begin{tabular}{cccc}
\hline $\begin{array}{c}\text { Plant spacing } \\
(\mathrm{m})\end{array}$ & $\begin{array}{c}\text { Basic density } \\
\left(\mathrm{g} / \mathrm{cm}^{3}\right)\end{array}$ & $\begin{array}{c}\text { Thickness } \\
(\mathrm{mm})\end{array}$ & $\begin{array}{c}\mathrm{GCV} \\
(\mathrm{kcal} / \mathrm{kg})\end{array}$ \\
\hline $1(3 \times 0.5)$ & $0.317 \mathrm{~b}$ & $3.024 \mathrm{a}$ & $4037 \mathrm{a}$ \\
$2(3 \times 1)$ & $0.319 \mathrm{ab}$ & $3.424 \mathrm{a}$ & $3980 \mathrm{a}$ \\
$3(3 \times 1.5)$ & $0.319 \mathrm{ab}$ & $3.077 \mathrm{a}$ & $4032 \mathrm{a}$ \\
$4(3 \times 2.0)$ & $0.330 \mathrm{ab}$ & $2.883 \mathrm{a}$ & $4093 \mathrm{a}$ \\
$5(3 \times 3)$ & $0.332 \mathrm{a}$ & $3.675 \mathrm{a}$ & $4086 \mathrm{a}$ \\
Mean & 0.323 & 3.217 & 4046 \\
\hline \multicolumn{2}{l}{ Same letters in column (same variable) indicate no difference between }
\end{tabular}
means by Tukey test at $5 \%$ significance level. 
Table 3 - Average values of the macronutrient minerals present in the bark, depending on the plant spacing. Tabela 3 - Valores médios de macronutrientes presentes na casca em função do espaçamento de plantio.

\begin{tabular}{|c|c|c|c|c|c|c|}
\hline Treatment & $\mathrm{N}$ & $\mathrm{P}$ & $\mathrm{K}$ & $\mathrm{Ca}$ & $\mathrm{Mg}$ & $\mathrm{S}$ \\
\hline \multicolumn{7}{|c|}{ Dag/kg (\%) } \\
\hline 1 & $0.273 a$ & $0.030 \mathrm{abc}$ & $0.212 \mathrm{a}$ & $0.409 a$ & $0.104 a$ & $0.024 \mathrm{a}$ \\
\hline 2 & $0.319 a$ & $0.041 \mathrm{a}$ & $0.202 \mathrm{a}$ & $0.443 a$ & $0.134 \mathrm{a}$ & $0.024 \mathrm{a}$ \\
\hline 3 & $0.294 \mathrm{a}$ & $0.032 \mathrm{ab}$ & $0.222 \mathrm{a}$ & $0.445 a$ & $0.133 a$ & $0.023 \mathrm{a}$ \\
\hline 4 & $0.278 \mathrm{a}$ & $0.025 b c$ & $0.182 \mathrm{a}$ & $0.460 \mathrm{a}$ & $0.126 \mathrm{a}$ & $0.023 \mathrm{a}$ \\
\hline 5 & $0.294 \mathrm{a}$ & $0.020 \mathrm{c}$ & $0.162 \mathrm{a}$ & $0.552 \mathrm{a}$ & $0.143 \mathrm{a}$ & $0.021 \mathrm{a}$ \\
\hline Mean & 0.292 & 0.030 & 0.196 & 0.462 & 0.128 & 0.023 \\
\hline
\end{tabular}

Same letters in column (same variable) indicate no difference between means by Tukey test at 5\% significance level.

Table 4 - Average values of the micronutrient minerals present in the bark, depending on the plant spacing Tabela 4 - Valores médios de micronutrientes presentes na casca em função do espaçamento de plantio.

\begin{tabular}{cccccc}
\hline Treatment & $\mathrm{Zn}$ & $\mathrm{Fe}$ & $\mathrm{Mn}$ & $\mathrm{Cu}$ & \\
\hline 1 & & & $\mathrm{mg} / \mathrm{kg}$ & & $\mathrm{B}$ \\
2 & $17.733 \mathrm{a}$ & $32.733 \mathrm{a}$ & $121.400 \mathrm{~b}$ & $3.200 \mathrm{a}$ & $11.267 \mathrm{a}$ \\
3 & $17.700 \mathrm{a}$ & $38.067 \mathrm{a}$ & $180.433 \mathrm{ab}$ & $3.700 \mathrm{a}$ & $10.467 \mathrm{a}$ \\
4 & $15.800 \mathrm{ab}$ & $19.000 \mathrm{a}$ & $259.000 \mathrm{ab}$ & $2.967 \mathrm{a}$ & $10.133 \mathrm{a}$ \\
5 & $16.533 \mathrm{ab}$ & $20.800 \mathrm{a}$ & $301.867 \mathrm{a}$ & $3.333 \mathrm{a}$ & $8.033 \mathrm{a}$ \\
\hline Mean & $13.667 \mathrm{~b}$ & $24.800 \mathrm{a}$ & $317.867 \mathrm{a}$ & $2.800 \mathrm{a}$ & $12.267 \mathrm{a}$ \\
\hline
\end{tabular}

Same letters in column (same variable) indicate no difference between means by Tukey test at $5 \%$ significance level.

\section{DISCUSSION}

The growth conditions of the trees, affected by the spacing, may explain the results of bark basic density. As is known, the wider the spacing; the lower the competition among trees, thus presenting greater growth capacity. Therefore, the greatest growth is directly related to physiological activity of the vascular cambium, that with better conditions, produce better structured cells, resulting in greater mass per unit volume of the cells formed due to the wider spacing (Evert, 2006).

The lowest phosphorous and zinc content in the bark occurred at the wider spacings, which, according to Müller (2005) can be explained by the lower amounts of these nutrients found at less spacing, after soil chemical analysis at 24 months. Assis et al. (2006) found that spacing did not influence the levels of N, P, S and B in of Eucalyptus urophylla S. T. Blake tree stands in the cerrado region in Bocaiuva, Minas Gerais, Brazil.

A range of factors, such as the plant physiology, soil composition and behavior of the soil nutrients can explain the difference in bark mineral content related to spacing. The participation of this mineral in the composition of enzymes and auxin could have determined the $\mathrm{Zn}$ content reduction with the spacing increase, since auxin is responsible for longitudinal growth of trees and the spacing of the population is directly related to this growth (Raven et al., 1996; Malta et al., 2002). Therefore, the lower the spacing, the higher the longitudinal growth and thus the $\mathrm{Zn}$ levels.

The root growth of trees, together with the immobility of this nutrient in soil, can be responsible for the lower $\mathrm{P}$ content at wider spacing. There is a higher level of competition for nutrients among roots at low spacing; consequently, the roots become longer. This fact may have contributed to better phosphorus assimilation, since this nutrient is immobile and has a particular way of interacting with soil components. The different oxidation states of manganese, its absorption by trees or its physiological function for photosynthesis influencing the growth phase may explain the increasing of $\mathrm{Mn}$ levels in the bark with the spacing increase.

According to Collet (1955), cited by Vital et al. (1989), all mineral components found in wood and the highest concentration in the bark, are passed on to the charcoal. If production of some types of iron alloys is intended, the presence of some mineral components can be undesirable. Thus, we can consider that the bark, in general, is the main source ofminerals found in charcoal, and even in small amounts, is undesirable. Phosphorus, for example, is a mineral that when incorporated into the alloys, results in their becoming brittle and less malleable resulting in conditions favorable for the propagation of cracks and fissures.

Revista Árvore. 2018;42(5):e420501 

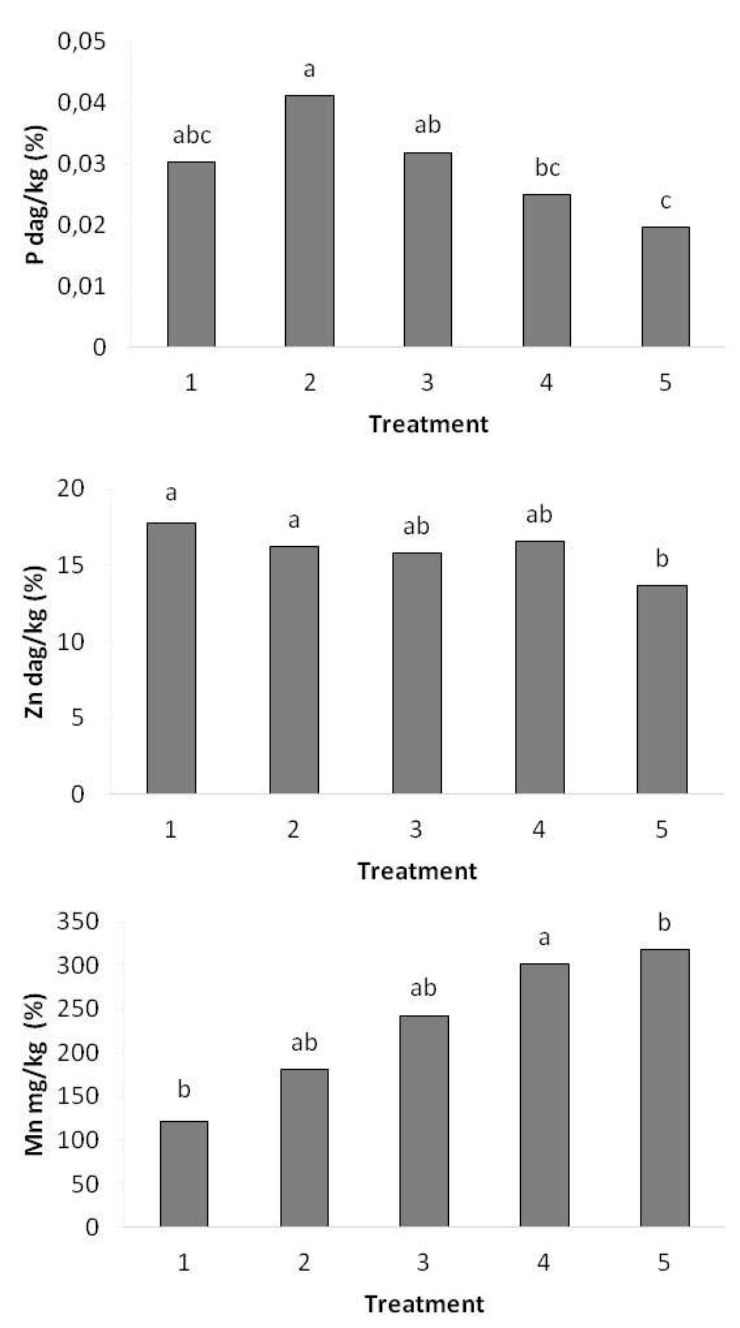

Figure 1 - Mean values of phosphorus (A), zinc (B) and manganese $(\mathrm{C})$, respectively, present in the bark, depending on the plant spacing.

Figura 1 - Valores médios de fósforo (A), zinco (B) e magnésio (C), respectivamente, presentes na casca, em função do espaçamento de plantio.

Moreover, the mineral content is undesirable for activated carbon production. For an activated carbon to have good adsorption properties, it is necessary that the raw materials have the least amount of mineral content in their composition, as this minerals may react with chemicals upon activation and the surface modification process, which may cause obstructions in pore structure (Bansal and Goyal; 2005).

Müller (2005) stated that when the bark from harvested trees is left in the field, nutrient supply to the soil increased. This highlights the importance from the point of view of soil fertility and aslo exploitation of wood without bark in short-duration rotation systems for power generation.

\section{CONCLUSION}

Spacing affected the bark properties;.growth conditions and tree physiology influenced all these properties.

Spacing affects the basic density of bark in this study and the highest basic density level was found at the widest spacing.

Finally, the widest spacing produced highest bark basic density, lowest $\mathrm{Zn}$ and $\mathrm{P}$ content and highest Mn content compared with low spacing.

\section{REFERENCES}

Andrade AM. Influência da casca de Eucalyptus grandis W. HILL ex MAIDEN no rendimento e qualidade de carvão vegetal [dissertação] Viçosa, MG: Universidade Federal de Viçosa; 1989.

Assis RL, Ferreira MM, Cargnelutti Filho A. Estado nutricional de Eucalyptus urophylla s.t. blake sob diferentes espaçamentos na região de cerrados de Minas Gerais. Pesquisa Agropecuária Tropical. 2006;36(3):151-7.

Associação Brasileira de Normas Técnicas ABNT. Normas técnicas NBR 8633. Brasília, DF: 1983.

Associação Brasileira de Normas Técnicas ABNT. Normas técnicas NBR 11941. Brasília, DF: 2003.

Bansal RC, Goyal M. Activated carbon adsorption. Boca Raton: CRC Taylor \& Francis; 2005.

Empresa Brasileira de Pesquisa Agropecuária Embrapa. Serviço Nacional de Levantamento e Conservação de Solos. Manual de métodos de análise de solo. $2^{a}$ ed. Rio de Janeiro: 1997.

Evert RF. Esau's plant anatomy. 3rd.ed. New Jersey: Wiley-Interscience; 2006.

Hall DO. Biomass energy. Energy Policy Renewables series. 1991.p.711-37.

Revista Árvore. 2018;42(5):e420501 
Malta MR, Furtini Neto AE, Alves JD, Guimaraes PTG. Efeito da aplicação de zinco via foliar na síntese de triptofano, aminoácidos e proteínas solúveis em mudas de cafeeiro. Brazilian Journal of Plant Physiology. 2002;14:31-7.

Brasil. Ministério de Minas e Energia. Projeto Cadastro de Fontes de Abastecimento por Água Subterrânea Vale do Jequitinhonha. Diagnóstico do Município de Itamarandiba-MG, 2005.

Müller MD. Produção de madeira para geração de energia elétrica numa plantação clonal de eucalipto em Itamarandiba, $M G$ [tese]. Viçosa, MG: Universidade Federal de Viçosa; 2005.

Programa das Nações Unidas para o Desenvolvimento - PNUD. Atlas de Desenvolvimento Humano para o Brasil. 2000. [acessado em: 30 mar. de 2015] Disponível em: www.penud.org.br/atlas/.

Raven PH, Evert RF, Eichhorn SE. Biologia vegetal. $5^{\text {a }}$. ed. Rio de Janeiro: Guanabara Koogan; 1996.738 p.

Rocha MFV. Influência do espaçamento e da idade na produtividade da madeira de Eucalyptus grandis $x$ Eucalyptus camaldulensis para energia [dissertação]. Viçosa, MG: Universidade Federal de Viçosa; 2011.

Stappe JL, Balloni EA. O uso de resíduos da indústria de celulose como insumos na produção florestal. IPEF.1988(40):33-7.

Vital BR, Andrade AM, Valente OF, Campos JCC. Influência da casca no rendimento e na qualidade do carvão vegetal de Eucalyptus grandis. IPEF. 1989;41/42:44-9. 